DOI:10.17951/bc.2021.6.63-82

\begin{tabular}{lcr}
\hline & ANNALES \\
& UNIVERSITATIS MARIAE CURIE-SKŁODOWSKA & \\
LUBLIN - POLONIA & \\
VOL.VI & SECTIO M & 2021 \\
\hline
\end{tabular}

\author{
Norbert Honka \\ University of Opole, Poland \\ nhonka@uni.opole.pl \\ ORCID 0000-0002-4029-4985
}

\title{
The formation of local territorial administration in Poland in the years 1945-1952
}

\section{Introduction}

The end of World War II initiated many changes in Central and Eastern Europe, including Poland. The repercussions of the war were felt for decades, especially in the sphere of administration. Taking control of local administration turned out to be an indispensable condition for maintaining power by the grouping that, at the time of the liberation of the eastern Polish territories, was an organisation without broad social support. The recent anniversary of the rebirth of local government in Poland constitutes an opportunity to analyse the beginnings of the formation of local administration in Poland after World War II.

The aim of this paper is to analyse the legal basis, as well as the social and political realities related to the functioning of local territorial administration. It will allow for better understanding of the ways of its systemic and structural functioning. The paper has some time barriers resulting from the adopted research topic. The chronological framework is related to two socio-political events: the end of World War II and the building of a new legal and administrative order in the territory of Poland, as well as the enactment of the Constitution of the People's Republic of Poland in 1952. A small exception in this respect is commencing the analysis from the year 1944. This is due to the fact that the eastern territories of present-day Poland were liberated from Nazi occupation in 1944, and 
it was at this moment that the practical formation of territorial administration on Polish soil began. Addressing this topic is intended to draw attention to the issues that to a considerable extent determined the shape of local and regional administration for many years.

The defining research questions are intended to help in verifying the adopted research hypotheses. These are: What internal and external factors determined the reconstruction of local territorial administration in Poland? In what direction was the reconstruction of local territorial administration heading in Poland after World War II? Did the local territorial administration in Poland have an impact on the reconstruction of statehood and democracy? What models of local territorial administration functioned in Poland in the years 1945-1952?

Based on the examination and analysis of source and other materials, the following hypotheses are formulated: the longer the functioning of local government was maintained within local administrative structures, the more evident was the opportunism of this move; the more communist power was consolidated in Poland, the stronger was the tendency to build a uniform centralised model of administrative power at all levels.

The issue of the formation of local administration in Poland in the years 1945-1952 can be analysed from the perspective of political and administrative sciences, historical sciences, legal sciences, as well as geographical sciences. This is possible due to the multidimensionality and diversity of the subject matter. Thus, it is legitimate to apply simultaneously various research methods characteristic of individual sciences. While working on the subject matter of this paper, the author used the methods characteristic of historical sciences ${ }^{1}$, the statistical method $^{2}$, the method of systemic analysis ${ }^{3}$, the institutional-legal method ${ }^{4}$, the decision-making method ${ }^{5}$ and the deductive method. In addition to the research methods, the following research techniques were also applied: analysis and critique of the existing literature on the subject, as well as secondary analysis of the results of research conducted by other authors.

1 More on this topic: A. J. Chodubski, Wstęp do badań politologicznych, Gdańsk 2004, pp. $127-$ 128; A. Łuszczyński, Podstawy metodologiczne badań politologicznych, Rzeszów 2005, pp. 45-47.

2 More on this topic: A. Łuszczyński, op. cit., pp. 49-50.

3 More on this topic: A. J. Chodubski, op. cit., pp. 119-120; A. Łuszczyński, op. cit., pp. 3639.

4 More on this topic: A. J. Chodubski, op. cit., pp. 126; A. Łuszczyński, op. cit., pp. 48-49.

5 More on this topic: A. J. Chodubski, op. cit., pp. 130-131; A. Łuszczyński, op. cit., pp. 3942. 


\section{The local territorial administration in Poland 1944-1952}

Discussion on the political future of Poland after the end of the war started almost immediately after the outbreak of World War II. The debate took place on two levels: the international level - among the Allies, and the internal level - within Polish political circles functioning in the unoccupied allied countries and in occupied Poland. These issues began to gain momentum as of 1942. The groups operating in occupied Poland, which were part of the government in exile, established the National Political Representation (NPR) in March 1943. One of the areas discussed during debates on the future political system was administrative issues. In a declaration issued by the NPR on 15 August 1943, local government was recognised as the basis of the future political system ${ }^{7}$. This was equivalent to establishing a system based on the principles of democracy supported by decentralisation.

Meanwhile, at the other extreme was the Polish Workers' Party (PWP), which sympathised with the Soviet Union. As a political grouping, it also referred to the future post-war state governance. It did so very cautiously, focusing only on the question of borders, which was evident in its policy statement entitled What are we fighting for?8. There is nothing in it about a vision of the future political system of the state. This was also characteristic of the authorities in the initial period of their rule 9 . Entering the territory of today's eastern Poland, the new authorities faced a dilemma as regards the formation of local administration structures. Building its own administration in the field could consolidate the position of the PWP as an organisation holding power.

In rebuilding local administration structures, the authorities not only issued new regulations, but also resorted to the legal solutions from before World War II in order to convey the impression of continuity from the Second Republic. The new authorities referred to the "basic" provisions of the March Constitution of 1921, supplementing them with national councils, i.e. new forms of administration and exercise of power. How the basic provisions of the March Constitution were to be understood was never clearly and comprehensibly defined,

6 More on this topic: N. Honka, Ewolucja systemu samorzadu terytorialnego w Polsce po II wojnie światowej, Wrocław 2012, pp. 31-62.

7 More on this topic: K. Kersten, Narodziny systemu władzy. Polska 1943-1948, Poznań 1990, p. 23.

8 More on this topic: M. Kallas, A. Lityński, Historia ustroju i prawa Polski Ludowej, Warszawa 2003, p. 19; K. Kersten, op. cit., pp. 14-15, 23-24.

9 Cf. W. Kozyra, Ustrój administracji państwowej w Polsce w Latach 1944-1950, [in:] „Czasopismo Prawno-Historyczne” 2011, vol. LXIII, issue 1, p. 171. 
which allowed for their free interpretation and the use of only those provisions that were convenient for the authorities ${ }^{10}$.

Using the provisions of the defunct constitution was an unprecedented attempt to deprive the legal emigrant government in London of the foundations for its legal functioning. In a formal and legal sense, this meant that there was a gap in the historical process of the Polish state. However, in order to neutralise attacks of the emigrant groupings, a semblance of the continuity of democratic institutions, including local government, was maintained.

The State National Council (SNC) was an institution that played an important role in shaping the local administration system in Poland from 1944 onwards. It was established on the night from 31 December 1943 to 1 January 1944 in Warsaw ${ }^{11}$. During the meeting, The Provisional Statute of National Councils was approved ${ }^{12}$. Based on the March Constitution of $1921^{13}$, a three-tier structure of national councils was established: commune and municipal councils, district councils and provincial councils. The SNC granted itself supreme authority over them ${ }^{14}$. Despite intensive agitation, there was no support for cooperation within the SNC among left-wing and centre-left groupings. The council was joined by a few individuals from the Polish Socialist Workers' Party and the "People's Will" Peasants' Party, thus creating movements dependent on the PWP. The other organisations allegedly forming the SNC were verbal fiction created by the PWP ${ }^{15}$. Some studies of the PRP period confirmed the correctness of this assessment ${ }^{16}$.

From 1944 onwards, the system of national councils was governed by the principle of hierarchical subordination to higher-level councils. This was con-

${ }^{10}$ More on this topic: C. Ura, Samorzad terytorialny w Polsce Ludowej 1944-1950, Warszawa 1972, pp. 19-29; B. Zawadzka, Przedstawicielstwo w państwie socjalistycznym, Warszawa 1976, p. 17; W. Sokolewicz, Rady narodowe w konstytucji, [in:] „Studia Konstytucyjne”, vol. 4: Konstytucyjna regulacja systemu władzy lokalnej, ed. B. Zawadzka, Warszawa 1989, pp. 8-9. Cf. M. Klimek, Samorzad terytorialny w Polsce 1944-1950, [in:] „Przegląd Prawno-Ekonomiczny” 2009, issue 6, pp. 34-35; J. Itrich-Drabarek, Wptyw wydarzeń politycznych roku 1948 na ksztatt i funkcjonowanie administracji publicznej, [in:] Zwrot polityczny, 48 Między polska droga a projektem uniwersalnym, part 1, ed. M. Jabłonowski, W. Jakubowski, T. Krawczak, Warsaw 2013, p. 155.

${ }^{11}$ More on this topic: M. Kallas, A. Lityński, op. cit., p. 37; K. Kersten, op. cit., p. 35. Cf. M. Klimek, op. cit., p. 31; W. Kozyra, op. cit., pp. 173-174.

${ }^{12}$ Uchwała Krajowej Rady Narodowej z dnia 1 stycznia 1944 r. Statut Tymczasowy Rad Narodowych, [in:] Konstytucja i podstawowe akty ustawodawcze Polskiej Rzeczypospolitej Ludowej. Zbiór tekstów. Foreword by Kazimierz Biskupski, Warszawa 1954, pp. 51-56.

${ }^{13}$ Ibidem, Art. 1 of Statut. More on this topic: C. Ura, op. cit., p. 20.

${ }^{14}$ Uchwała Krajowej Rady Narodowej z dnia 1 stycznia 1944 r. Statut tymczasowy Rad Narodowych, op. cit., Art. 2 and 8 of Statut. Cf. M. Klimek, op. cit., p. 31; W. Kozyra, op. cit., p. 174.

${ }^{15}$ More on this topic: M. Kallas, A. Lityński, op. cit., p. 36; K. Kersten, op. cit., p. 35.

${ }^{16}$ B. Zawadzka, Przedstawicielstwo..., pp. 16-17; C. Ura, op. cit., pp. 20-21. Cf. M. Klimek, op. cit., pp. 33-35. 
trary to the principle of decentralisation. The implementation of the system of councils meant only concentration of power. The most important element, however, was the control over the functioning of individual levels of administration, including their communities.

Despite the fact that they were described at the initial stage as "temporary bodies", according to the authors of some studies, national councils became the underground power and political representation of the nation ${ }^{17}$. Using such a statement in a description of that period was an illusion because the structures of the underground Polish state with the legal government in London had functioned since the beginning of the war. On the other hand, the structures of the SNC were one of many institutions active in the territory of occupied Poland. It did not even have the support of the USSR at that time. It was only in May and July 1944 that the SNC delegation reached an agreement with the communists from the Union of Polish Patriots, which was approved personally by Stalin. The consequence of that agreement was the establishment of the Polish Committee of National Liberation (PCNL). It was agreed that the SNC would assume the functions of a legislative body, and PCNL - the functions of an executive body. On the same day, the text of a proclamation to the inhabitants of Poland in Polish and Russian was agreed on and drawn up. It was entitled The Manifesto of the Polish Committee of National Liberation.

The Manifesto stressed that the basic principles of the Constitution of 1921 would remain in force until the new Sejm was elected. It was stated that the PCNL exercised its powers through provincial, district, municipal and commune national councils ${ }^{18}$. The Manifesto's general declaration about the way powers were exercised was implemented on the basis of three legal acts. The first one was the PCNL's decree of 21 August 1944 on the procedure for appointing general administrative authorities of the first and second instance ${ }^{19}$.

The decree established the following territorial executive bodies of the government administration: provincial offices headed by provincial governors in the second instance, and district offices headed by district governors in the first

${ }^{17}$ More on this topic: T. Bocheński, S. Gebert, J. Starościak, Rady narodowe. Ustrój i dziatalność, Warszawa 1971, pp. 17-18; T. Bocheński, S. Gebert, J. Służewski, Rady narodowe i terenowe organy administracji państwowej, Warszawa 1977, p. 18; A. Wendel, Z. Zell, Rady narodowe w PRL, Warszawa 1968, pp. 6-10; B. Słobodzian, Wspótczesny system samorzadu terytorialnego, Toruń 2006, p. 37.

${ }_{18}$ Journal of Laws 1944, no. 1, Annex. Cf. J. Itrich-Drabarek, op. cit., p. 157; M. Klimek, op. cit., p. 31; W. Kozyra, op. cit., pp. 175-176.

19 Dekret Polskiego Komitetu Wyzwolenia Narodowego z 21 sierpnia 1944 r. o trybie powotywania władz administracji ogólnej I i II instancji, Journal of Laws 1944, no. 2, item 8. 
instance. Provincial and district governors were ex officio members of provincial and district national councils. Formally, their appointment and dismissal could only take place after consultation with the relevant councils. Simultaneously, a solution aimed at unifying the administration system was applied. In matters of local government, provincial and district governors were subordinated to their respective provincial and district national councils ${ }^{20}$. The Decree, with minor deviations, was drafted on the basis of the Regulation of the President of the Republic of Poland of 19 January 1928 on the organisation and scope of activity of general administrative authorities ${ }^{21}$.

The second legal act was the Act of 11 September 1944 on the organisation and scope of activity of national councils ${ }^{22}$. This document also indicated the direction in which the system of administration was to develop. Based on the March Constitution, the Act stated that national councils were temporary legislative and local governmental bodies in the liberated territories ${ }^{23}$.

An important issue in building the administration system and its bodies was the model of appointment. According to the Act, there would be no elections and the method of establishing councils would be based on the principle of delegation and co-optation. The right to delegate was given to "democratic" and "independence" organisations linked to the communist movement. A solution was also introduced to break up the London government's groups and legitimise the new authorities. The Act allowed for the co-optation of distinguished and prominent people to councils. Furthermore, it provided for interconnections among councils of different levels and their bodies. Municipal and commune councils delegated one representative from their presidiums to district councils. District councils and municipal district councils delegated two representatives from their presidiums to provincial national councils. Provincial councils and the municipal councils of Warsaw and Łódź each delegated five representatives to the $\mathrm{SNC}^{24}$. Abandoning the formation of collegial bodies by way of general elections was an intentional step. It resulted from the weak position of the au-

${ }^{20}$ Journal of Laws 1944, no. 2, item 8, Art. 1, Art. 3, Art. 7-10. More on this topic: C. Ura, op. cit., pp. 49-50.

21 More on this topic: B. Dolnicki, Samorzad terytorialny, Zakamycze 2003, p. 54; M. Kallas, A. Lityński, op. cit., p. 59; Z. Leoński, Rady Narodowe. Zasady organizacji i funkcjonowania, Warszawa 1969, p. 7.

22 Journal of Laws 1944, no. 5, item 22.

23 Ibidem, Art. 1.

${ }^{24}$ Ibidem, Art. 4-7. More on this topic: C. Ura, op. cit., pp. 41-48; B. Zawadzka, Przedstawicielstwo..., pp. 158-163; W. Kozyra, op. cit., pp. 176-177, 181-184, 186-187. 
thorities in the liberated territories and the need to build a new political system with faithful administrative bodies.

National councils played a significant role in the building of the new political and administrative system. They appointed local government executive bodies - provincial departments, district departments, as well as municipal and commune boards, planned public activities, and fulfilled controlling functions with respect to central government and local government executive bodies. A provincial department was headed by a provincial governor. A district department was managed by a district governor. The most important element for the functioning of national councils was the guidelines formulated by the SNC and its basic line of activity. However, it was not clearly declared how this should be understood, which left a lot of space for interpretation. Councils also had the right to enact local laws, with the proviso that each time they had to receive a delegation from the $\mathrm{SNC}^{25}$.

National councils functioned on the basis of the principle of hierarchical subordination. A lower-level council was subordinate to a higher-level council. The supreme body of this hierarchy was the SNC, and later the Sejm of the People's Republic of Poland. The SNC determined and controlled the scope and direction of activity of lower-level councils. It could dissolve any local council irrespective of its position in the hierarchy. Moreover, it could exclude individual members from the composition of any council ${ }^{26}$.

The third legal act, the PCNL's decree of 23 November 1944 on the organisation and scope of activity of the local government system ${ }^{27}$, reinstated local government bodies. It was based on the Act of 23 March 1933 on the partial change of the local government system. The already known elements defining the possession of a legal personality and a public law corporation were supplemented by representation by a territorial national council ${ }^{28}$. The local government system was characterised by a limited legal personality or even the lack thereof. It should be noted that in the interwar period, the local government system functioned in rural and urban communes, as well in the Śląskie, Pomorskie and Poznańskie

${ }^{25}$ Journal of Laws 1944, no. 5, item 22, Art. 21-23, 28, 29. More on this topic: C. Ura, op. cit., pp. 142-143, 160-161; B. Zawadzka, Przedstawicielstwo..., p. 18; W. Kozyra, op. cit.

${ }^{26}$ Journal of Laws 1944, no. 5, item 22, Art. 21-23. More on this topic: W. Kozyra, op. cit.

27 Dekret Polskiego Komitetu Wyzwolenia Narodowego z dnia 23 listopada 1944 r. o organizacji i zakresie działania samorzadu terytorialnego, Journal of Laws 1944, no. 14, item 74.

28 Journal of Laws 1944, no. 14, item 74, Art. 3. More on this topic: C. Ura, op. cit., p. 17; J. Itrich-Drabarek, op. cit, p. 161; W. Kozyra, op. cit., pp. 184,187. 
provinces. The decree established provincial local government associations in each province ${ }^{29}$.

The scope of tasks of the local government included public matters of local importance, with the proviso that matters falling within the remit of state administration were excluded. The decree also listed the spheres in which the local government would not be involved: foreign affairs and international trade, armed forces, administration of justice, transport, postal service and telecommunications, state taxes, fees, duties, excises and monopolies ${ }^{30}$. The activities of the local government and its executive bodies were under the supervision of the central government. This supervision was exercised by the Head of the Ministry of Administration ${ }^{31}$. The decree consolidated the hierarchical subordination of national councils.

The executive body of a provincial national council was a provincial department headed by a provincial governor or their deputy. Its composition was supplemented by 6 persons chosen from the provincial council or from among the province's inhabitants. A candidate for a member of the department had to have 6 years of work experience in state or local government or social institutions ${ }^{32}$. The tasks of the department included preparing matters for the provincial council's sessions, making decisions on matters not reserved for the competence of other bodies, implementing the provincial council's resolutions and exercising disciplinary authority over presidents and vice-presidents, members of boards and councils of incorporated towns and cities. The HMA functioned as a body of appeal in the case of fines, while appeals against disciplinary sanctions were dealt with by the SNC presidium. The executive body of a district council was a district department headed by the district governor appointed by the central government on motion of the provincial governor. The district department functioned on the basis of the adapted regulations of the provincial department. It exercised disciplinary authority over mayors, commune heads, village leaders, members of the boards of rural communes and unincorporated towns. With respect to fines, the provincial governor fulfilled the function of a body of appeal; the presidium of the provincial national council was responsible for disciplinary matters. The chairperson convened meetings of the department at least once every fortnight or at the request of two of its members. In the event

\footnotetext{
${ }^{29}$ More on this topic: C. Ura, op. cit., p. 27.

${ }^{30}$ Journal of Laws 1944, no. 14, item 74, Art. 1-2. More on this topic: C. Ura, op. cit., pp. 143-145.

${ }^{31}$ Ibidem, Art. 8. More on this topic: W. Kozyra, op. cit., pp. 187-188. Hereinafter, the HMA.

32 Journal of Laws 1944, no. 14, item 74, Art. 10-13. More on this topic: C. Ura, op. cit., pp. 102-104.
} 
of a voting balance, the chairperson had the casting vote. Furthermore, in urgent matters within the competence of the department, the chairperson could take a decision on their own. Nevertheless, such a decision had to be approved at the next meeting of the department ${ }^{33}$.

The executive body in a municipal national council was a town board. It was managed by presidents with vice-presidents in incorporated cities and mayors with vice-mayors in unincorporated cities. In addition, depending on the decision of the council, the board consisted of from 3 to 6 members. The municipal council elected a president and vice-president or a mayor and vice-mayor. The election of a president and vice-president was subject to approval by the HMA, while elected mayors and vice-mayors had to be accepted by the provincial governor. The presidents of incorporated towns and cities acted simultaneously as heads of municipal districts, which resulted in their official subordination to the provincial governor ${ }^{34}$.

At the level of communes, it was a commune board that functioned as the executive body of a commune national council. The commune board consisted of a commune leader, their deputy and three ordinary members. Members of commune boards were elected in the same way as mayors and members of municipal boards. The election of a commune leader and their deputy had to be approved by the district governor. In the exercise of their powers, commune leaders were supported by village leaders and their deputies, who were elected by local inhabitants. Village leaders could participate in commune board meetings in an advisory capacity in matters concerning their villages ${ }^{35}$.

As regards the scope of activity of municipal and commune national councils and their executive bodies, the PCNL decree referred to Articles 43-48 of the Act of 23 March 1933 on the partial change of the local government system, in the wording adopted in 1935 . However, it also stated clearly that some provisions of these articles did not apply ${ }^{36}$. The decree abolished the separation of the local government from the central government and its local representatives. The local government system was placed under the management of the hierarchical structure of territorial national councils. On 6 May 1945, an amendment to the decree was passed, according to which persons fulfilling functions in the state or

33 Journal of Laws 1944, no. 14, item 74, Art. 14-22. More on this topic: C. Ura, op. cit., pp. 97, 99, 102-107, 110; W. Kozyra, op. cit., pp. 188-189.

34 Journal of Laws 1944, no. 14, item 74, Art. 24-29. More on this topic: C. Ura, op. cit., pp. 97-102; W. Kozyra, op. cit., pp. 188-189.

35 Journal of Laws 1944, no. 14, item 74, Art. 30-32. More on this topic: C. Ura, op. cit., pp. 97-102; W. Kozyra, op. cit., pp. 188-189.

36 Journal of Laws 1944, no. 14, item 74, Art. 33. 
local government administration could not sit in the SNC presidium ${ }^{37}$. On the same day, the organic statute of the Śląskie province was abolished ${ }^{38}$.

However, there were problems with the interpretation of the principles of the functioning of the local government system. This is reflected in the document of the Ministry of Public Administration (MPA). Ad hoc norms for rural, municipal and urban communes as part of the unification process were to be followed in the western and northern territories. However, they focused on issues of marginal importance ${ }^{39}$. The authorities abolished earlier solutions that were contrary to the new law, but according to MPA officials, the Prussian provincial law of 29 June 1875 had not been repealed in its entirety. Consequently, local government activists from Greater Poland demanded that the provinces be returned their full range of local government tasks, municipal property and the office of the national district governor. The Ministry rejected all such demands. Meanwhile, districts had to cope with controversies concerning the application of the provisions of the Act on the partial change of the local government system ${ }^{40}$. At the commune level, objections were raised against the membership of mayors and commune leaders in national councils if they were not included in their composition ${ }^{41}$. This problem also affected presidents of incorporated cities acting in the capacity of heads of municipal districts. Reservations about their status were voiced by provincial and district governors ${ }^{42}$. A major challenge was the lack of coordination within the government. The ministries of transport, industry, information and propaganda expropriated local government units of their property for the benefit of the state treasury, thus depriving them of a significant part of their income. At the same time, new obligations were being imposed on local government. These actions were taken without the knowledge of the MPA ${ }^{43}$. Another bone of contention was Warsaw, where the council adopted a resolution on the establishment of city quarter councils and of district national councils and municipal districts. This was supposed to increase the de-concentration of power by locating it closer to the citizen and improve city governance. The MPA considered that this was contrary to the Act of 11 September 1944 and destroyed

37 Journal of Laws 1945, no. 17, item 93.

38 Journal of Laws 1945, no. 17, item 92.

39 Archiwum Akt Nowych, Ministerstwo Administracji Publicznej w Warszawie, Departament Samorządu: Wydział Organizacji Samorządu 1945-1950, sygn. 2/199/0/1237, k. 1.2. Further: AAN, MAP, DS: WOS 1945-1950.

${ }^{40}$ Ibidem, k. 34-78.

${ }^{41}$ Ibidem, k. 214-268.

42 AAN, MAP, DS: WOS 1945-1950, sygn. 2/199/0/1277, k. 90, 96; sygn. 2/199/0/1278, k. 82-132.

${ }^{43}$ Ibidem, k. 3-32. 
the unity of the municipality by establishing six independent local government units. It stressed that the city had the status of a province, which excluded the possibility of creating a new hierarchical structure ${ }^{44}$.

In the amendment of 3 January 1946, the powers of local national councils were reduced to the planning of public activities and the exercise of control over local and central government executive bodies ${ }^{45}$. The amendment allowed for the establishment of city quarter councils as an auxiliary structure in cities with over 200,000 inhabitants ${ }^{46}$. At the same time, the number of councillors and persons co-opted to councils was increased ${ }^{47}$. According to the authorities, opportunities were created for the participation of broad social circles in governance. The amendment to the decree changed the rules for the election of council presidium members. Persons employed in the central government administration, local government administration and members of presidiums of other local councils were allowed to perform functions in council presidiums after obtaining the approval of the presidium of a higher level council. It was decided that the appointment of finance, budget, education and control committees as council bodies was obligatory. Other committees were to be established as the need $\operatorname{arose}^{48}$.

The amendment to the decree finished the first stage of the formation of local authorities. In 1946, Poland had 14 provinces, 2 cities with province rights, 271 districts, 44 cities with district rights, over 400 unincorporated towns, close to 3,000 communes and over 40,000 communities. Communities did not have national councils at that time, hence they could not be treated as basic units of administrative division ${ }^{49}$. On 19 February 1947, the Small Constitution was passed. The dependence of local national councils on the SNC was replaced by subordination to the new governing body, i.e. the State Council ${ }^{50}$.

The communist authorities sought to legitimise their rule at every level. Initially, being relatively unconsolidated, they had to reckon with the attachment of society to the local government system functioning in the Second Republic. The existence of democratic parties and organisations was not without significance.

${ }^{44}$ AAN, MAP, DS: WOS 1945-1950, sygn. 2/199/0/1237, k. 222-253.

${ }^{45}$ Journal of Laws 1946, no. 3, item 26, Art. $1 \$ 2$.

${ }^{46}$ Ibidem, Art. 2, $\$ 3$.

47 Ibidem, Art. 6. More on this topic: C. Ura, op. cit., p. 49.

${ }_{48}$ Journal of Laws 1946, no. 3, item 26, Art. 13, Art. 17, \$ 1, Art. 28.

${ }^{49}$ More on this topic: T. Bocheński, S. Gebert, J. Służewski, op. cit., p. 63.

${ }^{50}$ Journal of Laws 1947, no. 18, item 71, Art. 16a. More on this topic: W. Sokolewicz, Rady narodowe w konstytucji, op. cit., pp. 9-10. Cf. W. Kozyra, op. cit., p. 180; J. Itrich-Drabarek, op. cit., p. 160. 
Legitimisation was to be achieved as a result of free and democratic elections, which was a central item on the agenda of the Polish Peasants' Party that enjoyed high social support. Meanwhile, the PWP aimed to delay the holding of such elections. The activity of other political parties was being obstructed, and new regulations were introduced to the benefit of the PWP.

Cooperation between the general administration authorities and councils constituted an important element in the building of the new political system and the exercise of control over local governments. The essence of this supervision was the presence of general administration representatives at the meetings of national council presidiums ${ }^{51}$. The Ministry of Public Administration and the Ministry of Regained Territories were concerned about the attempt by the Regional Offices of Public Security (ROPS) to take over control of local governments and national councils. They issued a circular stating that the ROPS had claimed primacy over provincial and district governors, using illegal forms of pressure. It was emphasised that it was the duty of the ROPS to respect the authority of provincial and district governors, as well as to provide them with required information. The circular also mentioned the prohibition on giving orders to other governing bodies without proper authorisation ${ }^{52}$.

The unification congress of the Polish Workers' Party and the Polish Socialist Party in 1948 was followed by a complete seizure of control over the local government system. The Polish United Workers' Party removed inconvenient people from national councils and turned them into schools of obedient governance for its members. The remnants of the dualistic model of public administration were being continuously reduced and transformed into a model of consolidated state power ${ }^{53}$.

The understanding of local government by the authorities of that time can be found in the content of lectures delivered at an administrative course organised by the MPA in 1948. This content is the quintessence of the socialist idea of local government characterised by the unity of local governments and the central government, the central authorities' continuous supervision over tasks executed by representatives of local communities, as well as hierarchical structures ${ }^{54}$.

In the years 1944-1950, the system of public administration was formally dualistic. The local government system functioned beside the central government administration. This dualism was subject to strict control exercised by the gov-

51 AAN, MAP, Departament Polityczny: Wydział Społeczno-Polityczny 1944-1950, sygn. 603, k. 18, 31-34.

${ }^{52}$ Ibidem, k. 44-59, k. 159-162.

${ }_{53}$ Por. W. Kozyra, op. cit., p. 189; J. Itrich-Drabarek, op. cit., pp. 161-168

${ }^{54}$ AAN, MAP, DS: WOS 1945-1950, sygn. 2/199/0/1407, k. 31-121. 
ernment and the communist party. Moreover, all their activities in this respect were aimed at eliminating the dualism of governance. On 20 March 1950, the Sejm passed the act on local bodies of uniform state authorities, based on the Soviet concept of administration. Its result was a new constitutive administrative quality ${ }^{55}$. The adoption of the act was preceded by a vigorous propaganda campaign. It aimed to convince the public of the necessity of radical changes in the bad, inefficient and corrupt administrative system. Furthermore, the authorities asserted that the elimination of the dualistic system would make state governance more efficient and enable greater involvement of local communities in the government of their own affairs ${ }^{56}$.

It is worth emphasising that the diagnosis presented by the government was accurate. Overlapping competences, continuously implementing directives coming from higher levels, and exercising constant control over the activities of lower structures were not conducive to local development and support for stimulating the activity of local communities. Eliminating the dualism of power at the local and regional levels was the right solution, but it was taken in the wrong direction. The central government administration should have been removed and local government administration structures should have been developed.

The adopted act introduced a model of territorial state administration based on Soviet patterns. Local government executive bodies were abolished. This included: departments, boards and the offices of provincial and district governors, presidents, mayors and commune leaders. The matters for which they had been responsible were transferred to national councils headed by presidiums ${ }^{57}$. Furthermore, councils became local bodies of the consolidated state authority ${ }^{58}$. New rules for appointing national councils were also introduced.

For the purpose of passing the act, council members were appointed by socalled "parties and organisations of a democratic nature". From then on, council members were to be elected and dismissed by members of local communities.

55 Ustawa z dnia 20 marca 1950 r. o terenowych organach jednolitej władzy państwowej, Journal of Laws 1950, no. 14, item 130. More on this topic: W. Sokolewicz, Rady narodowe w konstytucji, op. cit., p. 10; J. Itrich-Drabarek, op. cit., pp. 164-165; M. Klimek, op. cit., pp. 35-37; W. Kozyra, op. cit., pp. 189-190.

56 More on this topic: T. Bocheński, S. Gebert, J. Służewski, op. cit., pp. 24-25; W. Sokolewicz, Rady narodowe w konstytucji, op. cit., pp. 10-11.

57 More on this topic: S. Zawadzki, J. Chwistek, Rady narodowe w Polskiej Rzeczypospolitej Ludowej, Warszawa 1981, pp. 25-26; W. Zakrzewski, Reformy systemu rad narodowych w Polsce a zagadnienie jednolitości wtadzy, „Problemy Rad Narodowych. Studia i materiały” 1976, no. 34, p. 6; B. Słobodzian, op. cit., p. 38; M. Chmaj, Geneza samorzqdu terytorialnego, [in:] Ustrój samorzadu terytorialnego w Polsce. Academic editor - Marek Chmaj, Warszawa 2005, p. 27.

58 Journal of Laws 1950, no. 14, item 130, Art.1, 2, 32-35. 
Matters related to the election and dismissal procedures, as well as active and passive voting rights, were left to be regulated in a separate act ${ }^{59}$. However, this issue was left aside for over 4 years. The wide range of competencies outlined in the act meant that councils, as bodies of local authorities, could decide on practically all matters ${ }^{60}$. In view of this, it does not seem right to narrow down this area only to the economic, social, cultural, defence and public security spheres as the authors of some studies $\mathrm{do}^{61}$.

It might appear that the essence of self-governance is the mass participation of citizens in the exercise of power ${ }^{62}$. However, the thesis expressed in this way does not seem justified. It is not confirmed by in the legislation or practical activity of post-war times. In the light of Article 4 of the Act of 20 March 1950, mass participation in the exercise of power would consist only in submitting demands, requests and complaints; in participating in unpaid community- or party-initiated work projects; in attending public meetings of councils and listening to reports on their activities ${ }^{63}$. This had no impact on governance and decision-making. Hierarchical dependence and the command-and-control system effectively blocked the implementation of even the most rational proposals.

For the execution of tasks in particular areas, national councils established permanent committees as their own internal and auxiliary bodies. Their tasks included the preparation of drafts of more important resolutions, the control over the activities of council bodies and the supervision of entities not subordinate to the council as a body of social control. In addition, the committees were obliged to be active in local communities with respect to propaganda and recruitment. The amended act maintained the system of vertical dependence of councils, presidiums and presidium departments ${ }^{64}$.

While allowing numerous decision-making centres to exist, the authorities failed to ensure the coordination of their activities. It was considered that in a command-and-control system, it was optimal to make decisions at the highest level and make lower levels responsible for their implementation; hence, coordination of plans and activities was unnecessary. It was not expected that the existence of multiple and uncoordinated decision-making centres at the highest level of government would inevitably lead to chaos.

${ }_{59}$ Ibidem, Art. 2, 3. More on this topic: B. Zawadzka, Przedstawicielstwo..., op. cit., pp. 19-20.

${ }^{60}$ Ibidem, Art. 6. Cf. W. Kozyra, op. cit., pp. 189-190; M. Klimek, op. cit., pp. 35-37.

${ }^{61}$ E.g.: Z. Leoński, op. cit., p. 14; B. Słobodzian, op. cit., pp. 38-39; S. Zawadzki, J. Chwistek, op. cit., p. 26; B. Zawadzka, Przedstawicielstwo..., p. 20.

${ }^{62}$ More on this topic: B. Słobodzian, op. cit., p. 39.

${ }^{63}$ Journal of Laws 1950, no. 14, item 130, Art. 4.

${ }^{64}$ Ibidem, Art. 11, 19. 
In post-war Poland, the presidium became the executive and managerial body of a council. Formally, the members of the presidium responsible for particular functions were chosen and dismissed by the council, but the last word belonged to the Council of Ministers, which had to receive the approval of the State Council beforehand. In addition, the Council of Ministers, also with the approval of the State Council, defined the rights, duties, division of powers of presidium members, as well as the procedures for the appointment and dismissal of employees of council bodies ${ }^{65}$. The tasks of the presidium included the fulfilment of managerial and executive functions of the administrative authority. The tasks of the chairperson of the presidium included planning and convening the presidium's meetings; managing its work; supervising the implementation of the council's and the presidium's resolutions, as well as enacting the guidelines received from upper-level authorities; and managing and supervising the work of the council's departments ${ }^{66}$. The powers of the chairperson of the council presidium limited the council's collegiality ${ }^{67}$.

In line with the government's decisions, the national council appointed another executive body - the council presidium department - which held responsibility for matters related to the execution of tasks within the scope of the council's competences. A novelty was the establishment, in addition to the vertical subordination system, of a horizontal subordination system in which particular bodies were directly or indirectly controlled by the council. The council directly controlled its committees and presidiums, while various departments were under its indirect supervision. Moreover, the departments of presidiums in commune, municipal, quarter and district councils were subordinate to their respective national councils and their presidiums, as well as to the corresponding departments in provincial national councils. The departments of the presidium of a provincial national council reported to that provincial council, its presidium, the Council of Ministers and individual ministers supervising the execution of particular types of tasks ${ }^{68}$. The establishment of an additional authority further complicated the already complex system of national councils.

The consolidation of the managerial and executive powers in national council presidiums was aimed at the dismantling of the specificity of executive authorities. The result could have been the liquidation of the competency-based

${ }^{65}$ Ibidem, Art. 12-15, 24.

${ }^{66}$ Ibidem, Art. 16-17.

${ }^{67}$ More on this topic: T. Bocheński, S. Gebert, J. Służewski, op. cit., pp. 26-27.

${ }^{68}$ Journal of Laws 1950, no. 14, item 130, Art. 1, 6, 15-21; Moe on this topic: Z. Leoński, op. cit., p. 15. 
independence of representative bodies and their reduction to the fulfilment of a façade and decorative function ${ }^{69}$.

Control over national councils was very strongly developed. The State Council was the institution that directly supervised councils and their bodies. Part of the supervision was exercised by the Council of Ministers and higher-level councils. The State Council could dissolve councils, as well as repeal resolutions of councils and their presidiums. Higher-level councils could also repeal resolutions of lower-level councils and their presidiums. In addition, the presidium of a higher-level council could repeal or suspend the implementation of a resolution of a lower-level council. Provincial national councils and their presidiums were also controlled by the Council of Ministers. Indeed, a suspension of a resolution of a provincial council had to be approved by the State Council ${ }^{70}$.

The Act on changes to the administrative divisions of the state of 28 June 1950 provided for the establishment of three new provinces, thus increasing the total number of provinces to 17 . This also meant the creation of new national councils at the provincial level. At the same time, changes were made at the district level in consequence of adjustments to provincial boundaries ${ }^{71}$.

The reform adopted in March 1950 provided for the granting of extensive general powers to local authorities. Many tasks of a local character remained within the competence of central authorities, while those that were granted to local government units fell within the scope of central tasks. The supervision of central government bodies over local government ones was increased. Indeed, sometimes the work of local councils was directly controlled by central authorities. The whole was complemented by the system of vertical and horizontal dependence. This political model is known as democratic centralism.

Implemented in 1950, the principles of the functioning of local bodies of the uniform state administration lasted with some modifications until 1958. The enactment of the Constitution of the People's Republic of Poland on 22 July 1952 was a crucial moment in this process ${ }^{72}$. Regardless of the assessment of the Constitution, the introduction of the provisions on national councils made them the norms of higher-order law. This entailed significant limitations because any systemic change in the area of national councils required an amendment to the Constitution ${ }^{73}$. The provisions concerning national councils were included in Chapter 5 entitled Local Bodies of State Authorities. They essentially repeated

\footnotetext{
${ }^{69}$ Por. W. Zakrzewski, Reformy systemu rad narodowych..., op. cit., p. 19.

${ }^{70}$ Journal of Laws 1950, no. 14, item 130, Art. 25-31.

${ }^{71}$ Journal of Laws 1950, no. 28, item 255. Cf. J. Itrich-Drabarek, op. cit., p. 165.

72 Journal of Laws 1952, no. 33, item 232.

${ }^{73}$ Ibidem, Art. 91.
} 
the most important regulations of the Act of 1950. In addition, there were provisions that defined, for example, terms of office or matters relating to the electoral law for councils ${ }^{74}$, e.g. the concessionary process of recommendation to run in Sejm or council elections. Candidates for elected offices had to receive formal support from political and social organisations operating in a particular area ${ }^{75}$.

A comparison between the Constitution and the Act of 20 March 1950 shows a significant difference. The Constitution does not contain the phrase "uniform local authorities". This marked a departure from the emphasis put on the uniformity of the administrative system, as opposed to a dualistic system based on territorial self-government represented by local national councils and state authorities ${ }^{76}$.

\section{Conclusions}

Undoubtedly the reconstruction of the local administration system in Poland after World War II was determined by both internal and external factors. The internal factors resulted directly from the external ones. The most important external factor was the political and military situation after the end of the war.

The process of reconstructing local administration in Poland was carried out under the banner of building democratic governance. Pro-democratic groups strove to rebuild democracy in both politics and local administration. For them, the institution that allowed the combination of these tendencies was local government. The communists adopted a different approach to this issue. For them, local government was only a tool to be used in pursuing their own political goals. The communist party had a weak position. As an organisation directly linked to the USSR, it did not enjoy wider support in society. Furthermore, until the unification in 1948, its position was made worse by the presence of the Polish Socialist Party (PSP), a political rival vying for the same electorate. Thus, the maintenance of the local government system for a certain period of time was necessary for the communists to consolidate their position, to unite their party with the PSP and to develop its own obedient administration by merging the systems of local government and national councils.

Between 1945 and 1950, the local government system was based on national councils. National councils were supposed to look after the interests of both

${ }^{74}$ Journal of Laws 1952, no. 33, item 232, Art. 34-45, 80-88. More on this topic: W. Sokolewicz, Rady narodowe w konstytucji, op. cit., pp. 11-12.

${ }^{75}$ Ibidem, Art. 86.

${ }^{76}$ More on this topic: W. Sokolewicz, Rady narodowe w konstytucji, op. cit., p. 12. 
local communities and the state. The coordination function of councils, consisting in ensuring consistency between the activities of the local government administration and the central government administration, was to be helpful in the execution of tasks. The functional axis was to be compatibility with the basic line of activity of the state and its highest authorities. The whole was to be supported by a hierarchical system of national councils and the principle of double subordination. However, the composition of national councils, which was not determined by way of democratic, free, secret, universal and equal elections, meant that they did not fulfil the function of representing local communities. They were established entirely on the basis of a process of delegation by so-called democratic organisations connected with the communist movement. As a result, local communities had no possibility to directly influence the formation of bodies of local authority and their functioning.

Bibliography

\section{Sources}

- Archiwum Akt Nowych, Ministerstwo Administracji Publicznej w Warszawie, „Departament Samorządu: Wydział Organizacji Samorządu 1945-1950", sygn. 2/199/0/1237, sygn. 2/199/0/1277, sygn. 2/199/0/1278, sygn. 2/199/0/1407; „Departament Polityczny: Wydział Społeczno-Polityczny 1944-1950", sygn. 603.

- Journal of Laws 1944, no. 2, item 8: Dekret Polskiego Komitetu Wyzwolenia Narodowego z 21 sierpnia 1944 r. o trybie powoływania władz administracji ogólnej I i II instancji, p. 6.

- Journal of Laws 1950, no. 14, item 130: Ustawa z dnia 20 marca 1950 r. o terenowych organach jednolitej władzy państwowej, pp. 172-175.

- Uchwała Krajowej Rady Narodowej z dnia 1 stycznia 1944 r. Statut Tymczasowy Rad Narodowych, [in:] Konstytucja i podstawowe akty ustawodawcze Polskiej Rzeczypospolitej Ludowej. Zbiór tekstów. Foreword by Kazimierz Biskupski, Warszawa 1954, pp. 51-56.

\section{Literature}

- Bocheński T., Gebert S., Służewski J., Rady narodowe i terenowe organy administracji państwowej, Warszawa 1977.

- Bocheński T., Gebert S., Starościak J., Rady narodowe. Ustrój i działalność, Warszawa 1971.

- Chmaj M., Geneza samorzadu terytorialnego, [in:] Ustrój samorzadu terytorialnego w Polsce. Academic editor - Marek Chmaj, Warszawa 2005, pp. 21-36.

- Dolnicki B., Samorzad terytorialny, Zakamycze 2003.

- Honka N., Ewolucja systemu samorzadu terytorialnego w Polsce po II wojnie światowej, Wrocław 2012. 
- Itrich-Drabarek J., Wptyw wydarzeń politycznych roku 1948 na ksztatt i funkcjonowanie administracji publicznej, [in:] Zwrot polityczny,48 Między polska droga a projektem uniwersalnym, part 1, ed. M. Jabłonowski, W. Jakubowski, T. Krawczak, Warszawa 2013, pp. 155-168.

- Kallas M., Lityński A., Historia ustroju i prawa Polski Ludowej, Warszawa 2003.

- Kersten K., Narodziny systemu wtadzy. Polska 1943-1948, Poznań 1990.

- Klimek M., Samorzad terytorialny w Polsce 1944-1950, [in:] „Przegląd PrawnoEkonomiczny" 2009, issue 6, pp. 30-39.

- Kozyra W., Ustrój administracji państwowej w Polsce w Latach 1944-1950, [in:] „Czasopismo Prawno-Historyczne” 2011, vol. LXIII, issue 1, pp. 171-191.

- Leoński Z., Rady Narodowe. Zasady organizacji i funkcjonowania, Warszawa 1969

- Słobodzian B., Współczesny system samorzadu terytorialnego, Toruń 2006

- Sokolewicz W., Rady narodowe w konstytucji, [in:] „Studia Konstytucyjne”, vol. 4: Konstytucyjna regulacja systemu władzy lokalnej, ed. B. Zawadzka, Warszawa 1989, pp. 5-57.

- Ura C., Samorzad terytorialny w Polsce Ludowej 1944-1950, Warszawa 1972.

- Wendel A., Z. Zell, Rady narodowe w PRL, Warszawa 1968.

- Zakrzewski W., Reformy systemu rad narodowych w Polsce a zagadnienie jednolitości władzy, „Problemy Rad Narodowych. Studia i materiały” 1976, issue 34, pp. 5-27.

- Zawadzka B., Przedstawicielstwo w państwie socjalistycznym, Warszawa 1976.

- Zawadzki S., Chwistek J., Rady narodowe w Polskiej Rzeczypospolitej Ludowej, Warszawa 1981.

Summary: The shaping of the local administration system in Poland in the years 1945-1952 is one of the most interesting issues in Poland's post-war history. On the one hand, there is a formally existing local government system, but on the other hand, there appears a Soviet administrative model of national councils, previously unknown in Poland. The combination of the systems of local government and national councils confused the administrative situation in Poland. The hierarchical arrangement of councils, i.e. the subordination of lower-level councils to higher-level ones, meant a departure from one of the basic features of local government, i.e. the independence of a given level of the administrative structure in relation to the level located above it. Moreover, the composition of national councils was not determined by way of elections, but only by a process of delegation by so-called democratic organisations closely linked to the communist movement.

Key words: local territorial administration, local government, Commune National Council, Municipal National Council, District National Council, Provincial National Council, State National Council, commune, district, province 
Kształtowanie się lokalnej administracji terenowej w Polsce w latach 1945-1952.

Streszczenie: Kształtowanie się systemu administracji lokalnej w Polsce w latach 1945-1952 jest jednym z najciekawszych zagadnień w powojennej historii Polski. Z jednej strony formalnie funkcjonował system samorządu terytorialnego, ale z drugiej strony pojawia się nieznany wcześniej w Polsce sowiecki model administracyjny rad narodowych. Połączenie systemów samorządu terytorialnego i rad narodowych skomplikował sytuację administracyjną w Polsce. Hierarchiczny układ rad, czyli podporządkowanie rad niższego szczebla radom wyższego szczebla, oznaczało odejście od jednej z podstawowych cech samorządu terytorialnego, czyli niezależności danego szczebla struktury administracyjnej w stosunku do poziomu znajdującego się nad nim. Co więcej, skład rad narodowych nie był ustalany w drodze wyborów, a jedynie w procesie delegacji przez tzw. organizacje demokratyczne ściśle związane z ruchem komunistycznym.

Słowa kluczowe: lokalna administracja terytorialna, samorząd lokalny, Gminna Rada Narodowa, Miejska Rada Narodowa, Powiatowa Rada Narodowa, Wojewódzka Rada Narodowa, Państwowa Rada Narodowa, gmina, powiat, województwo 